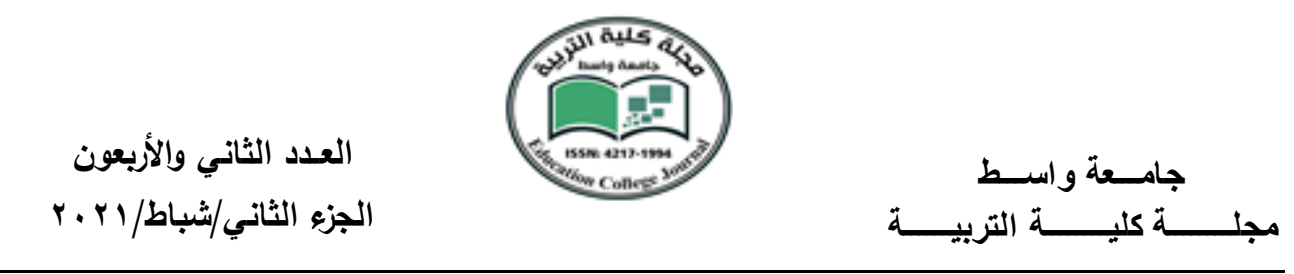

المؤسسات العامة في المدينة الإسلامية

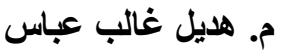

hadeel.abbas@ircoedu.uobaghdad.edu.iq

\author{
م.د. أريج احمد حسين
}

areej.ahmed@ircoedu.uobaghdad.edu.iq

جامعة بغداد / كلية التربية ابن رشد للعلوم الانسانية

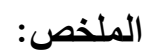

لقد تنوعت وتعددت المنشآت العامة في المدينة الإسلامية فمنها ما كان أغراض دينية ومنها

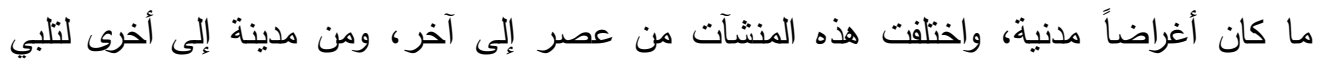

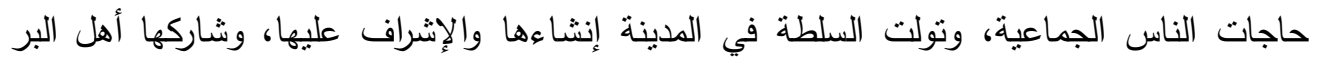

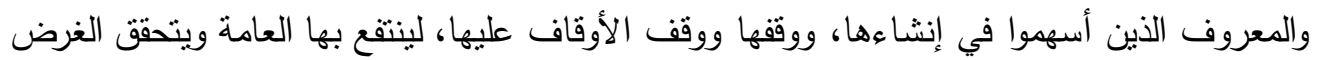
من إنشاءها.

وتعد المؤسسات العامة جانباً مهماً من جوانب الحياة في المدينة الإسلامية كالمساجد

والمدارس والمكتبات وغير ذللك من المؤسسات ومنشآتها المختلفة، لذلك فقد تم تقسيم بحثي هذا الى الى التي مبحثين المبحث الاول يتحدث عن المؤسسات الدينية التي تشمل المساجد ومنازل العلماء ومنشآت التصوف والمبحث الثاني يتحدث عن المؤسسات التعليمية التي تثمل الددارس والمكتبات وخزائن الكتب والإضاءة في المدينة.

\title{
Abstract:
}

The public establishments in the Islamic city have varied and varied, some of which were religious purposes, some of which were civil ones, and these facilities varied from one era to another, and from one city to another to meet the collective needs of the people. In establishing them, and endowing them, and endowments for endowments, so that the public can benefit from them and achieve the purpose of their establishment.

Public institutions are an important aspect of life in the Islamic city, such as mosques, schools, libraries, and other institutions and their various facilities. Therefore, my research has been divided into two chapters. The first topic talks about religious institutions that include mosques, scholars' homes, and mystic facilities. The second study talks about educational institutions that include Schools, libraries, bookcases and city lighting. 
العدد الثاني والأربعون

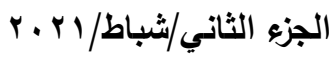
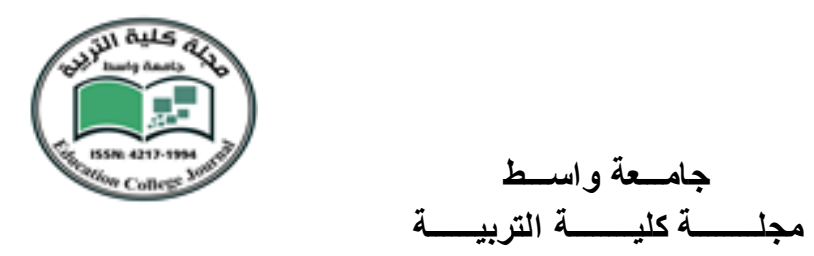

المقدمة:

تعددت المؤسسات العامة في المدينة الاسلامية ونقصد بها تلك المؤسسات التي يحتاجها عامة الناس

والتي تنتل غياب أي منها نقصاً واضحاً في حياتتا كالمساجد وامكان التعليم والطرقات العامة . لقد تتوعت وتعددت المنشآت العامة في المدينة الإسلامية فمنها ما كان أغراض دينية ومنها ما كان أغراضاً مدنية، واختلفت هذه المنشآت من عصر إلى آخر، ومن مدينة إلى أخرى لتلبي حاجات

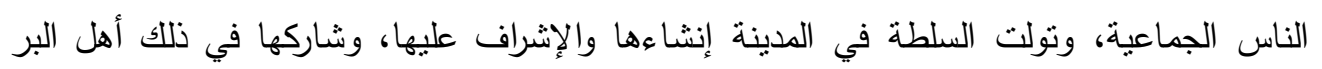
والمعروف الذين أسهموا في إنشاءها، ووققها ووقف الأوقاف عليها، لينتقع بها العامة ويتحقق الغرض وهن من إنشاءها.

وتعد المؤسسات العامة جانباً مهماً من جوانب الحياة في المدينة الإسلامية كالمساجد والمدارس والمكتبات وغير ذلك من المؤسسات ومنشآتها المختلفة، لذلك فقد نم تقسيم بحثي هذا الى مبحثين

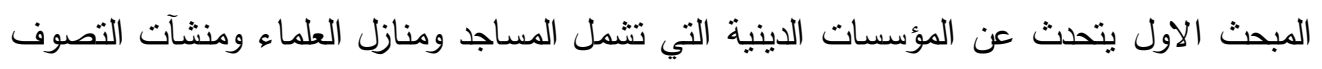
والمبحث الثاني يتحدث عن المؤسسات التعليمية التي تشمل المدارس والمكتبات وخزائن الكتب والإضناءة في المدينة.

"المؤسسات الاينيةة

ا - (المسجد: (1)

المسجد لغةً: اشتقت كلمة المسجد من الفعل سجد فيدل ذلك على انحناء الرأس أي الذل والخضوع لله

سبحانه وتعالى، والمسجد هو بيت الصلاة وكل موضع يتعبد فيه هو مسجد.(1)

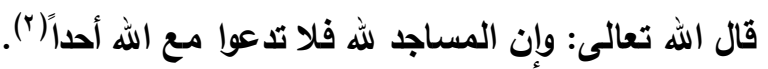

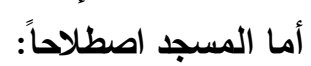

هو مركز الإشعاع الديني ورمزه في المدينة، والقلب الروحي فيها، وهو لا يتوسطها من الناحية

العمرانية فقط، ولكنه يتوسط الفكر الديني الإسلامي كله فيها أيضاً، وباعتباره قطبها الأول(َ). والظاهر أن المسجد كان مركز الحياة الروحية والعقلية والسياسية في مختلف المدن الإسلامية، كما استخدم للقضاء ولإجماع الناس، كما كان وأخيراً مركزاً لبحث الشؤون الدينية والتربوية

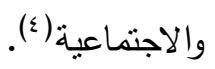

ففي المسجد استقبل الرسول (صلى اله عليه واله وسلم) سفراء الدول لتنظيم علاقته بدولهم، وفيه كان يخطب في جماعة المسلمين وينظم شؤونهم ويعلهم أمور دينهم، وفي زمن الخلفاء الراشدين كان الخلفاء يعلنون من منبر المسجد الأحداث التي تواكب الفتوحات ويرشدون الجيش بخطب تسبق 
العدد الثاني والأربعون

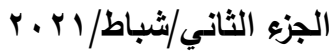

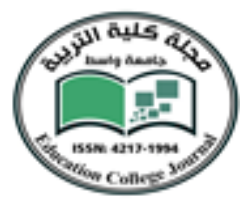

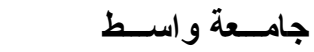

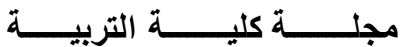

تحركه( (1) فكان المسجد هو الذي يجمع المسلمون ويبلغهم بالموقف فكان المسجد هو الذي يجمع المسلمون وبيلغهم بالموقف السياسي ومقررات الدولة أو يتلو عليهم أخبار المسلمين في البلاد الأخرى

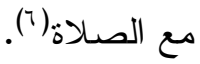

أخذ المسجد هذه الأهمية من موقعه في المدينة باعتباره النواة الأساسية في تخطبطها، فقد كان أول ما يختط ومن حوله تخطط خطط المدينة، وتتتهي إليه شوارعها وسككها وأزقتها، وكانت مدينة الرسول صلى الله عليه واله وسلم) المثال الأول على ذلك، فقد كان مسجد الرسول صلى الله عليه واله وسلم) أول شيء اختط في وسط المدينة('). وسارت مدن الأمصار الناشئة على هذا النهج في اختيار موضع متوسط في المدينة لإقامة المسجد ومن أمنتة نلك البصرة والكوفة والفسطاط والقيروان وغيرها(^). ولقد كان الهُف من اختبار الموضع المتوسط لإنشاء المسجد في المدينة الإسلامية لكثرة وظائفه، ليكون قريباً من كل أطراف المدينة حتى يسهل على المصلين التوجه إليه سواء كان من أهل المدينة أم المناطق المجاورة لها(9) وقد تكاثرت المساجد في المدن بمقدار التكاثر السكاني وكثافته، من فترة إلى أخرى ليتسع لهذه الأعداد النامية من المصلين، وأصبحت ظاهرة توسيع المساجد ظاهرة عامة في ناريخ الكثير من المساجد في المدينة الإسلامية كالمسجد الجامع في البصرة والكوفة وبغداد وقرطبة وغيرها(·) وبلغ عددها في البصرة في القرن الثالث للهجرة حوالي سبعة آلاف مسجداً وكان عدد مساجد قرطبة في أواسط القرن الرابع للهجرة اربعمائة وتسعون) مسجداً على حد قول ابن حوقل (' 'أو ثناثة آلاف حسب قول فئ ابن جبير (r'). وتتباهى المدن الإسلامية وما تزال بسعة مساجدها، واذا كانت السعة ناجمة عن سعة المدينة وكثرة سكانها بصورة أساسية فأن تزبينها إنما يرجع إلى أمرين شدة التقى وغنى الدولة التي تبنيها، وتعبر الشعوب كلها عن تقاها بالزينة التي تهبها لمساجدها. وليس يشذ المسلمون عن ذلك. فالتقى جانبه الفني وجانبه الديني من جهة أخرى ونعني جانب التقى والبذل من أجل الله سبحانه وتعالى فالتأنق في البناء زيادة في التقى والتقرب من اله(ب(ا) وقد عرفت المدن الإسلامية عدداً حسناً من الجوامع الواسعة لكل السعة، وكان أولها دون شك مسجد مكة الذي أقيم حول الكعبة وقد طهره الرسول الأعظم من الأوقات بعد أن جعله الله قبلة المسلمين. والكعبة مكعب طول ضلعه rام تقريباً، ويقوم من حولها ساحة واسعة هي صحن المسجد للطواف والصلاة ويحيط بالصحن أروقة تحملها أقواس على أعمدة . 
العدد الثاني والأربعون

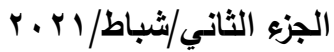

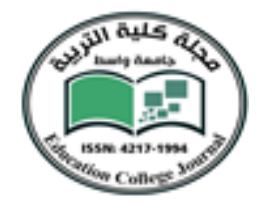

والكعبة مغشاة بستار ، كان الخلفاء العباسيون ثم الفاطميون بتبارون في تزبينه بالآيات الزهية وإهدائه كل سنة إليها، وقد جدد هذا المسجد "عدة مرات تبعاً للحاجة التي تظهر مع ازدياد عدد المسلمين"

وبعد ذلك انتشرت ظاهرة إنشاء المساجد الجامعة في المدينة الإسلامية، بل إن مساجد الخمسة

والمدارس التي كانت نشتنل على مساجد، وكذلك الخانقات(10) مفردها خانقة والخانقة كلمة فارسية الاصل مشتقة من الخان وهو البيت ثم اطلقت على رباط الصوفية عند المسلمين ومعنى خانقاه في الاصل هي البيوت التي كانت تقام لإيواء الصوفية الذين كان يختلون اليها للعبادة وكانت تعرف

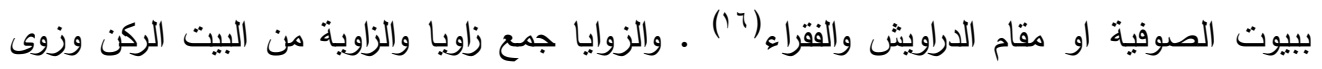

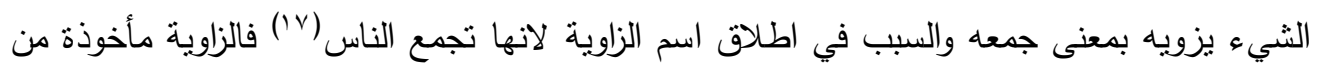
فعل انزوى بمعنى اتخذ ركنا من اركان المسجد للاعتكاف والتعبد(^/)حولت الكثير منها الى مساجد جامعة بإضافة منبر وتعيين خطيب. وتعتبر القاهرة من المدن الإسلامية التي انتشرت فيها هذه

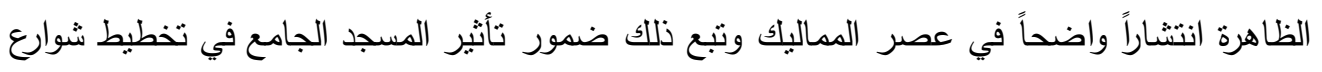
المدينة (19) - (19).

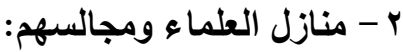

لقد كان لمنازل العلماء دور كبير في رفد المراكز الدينية في المدينة الإسلامية، ولاسبما في القرون الأولى إذ لم تظهر المدارس والربط(·r) مفردها رباط مشنقة من ربط الثيء اي شده واصل الرباط مرابط الخيل وهو ارتباطها بازاء العدو في بعض الثغور لمنعه من الدخول الى بلاد المسلمين ، اي ان اهل الاربطة يقضون حياتهم في التذريب العسكري والحراسة وفي التعبد لله سبحانه وتعالى، ووصف الرباط ايضا بانه الاقامة على جهاد العدو لذلك اقترنت تسمية المجاهد بالخيل ، فاصل الرباط مايربط به الخيل فالمجاهد هو المرابط(r) ، فقد كان الكثير من العلماء يعقدون مجالسهم العلمية سواء أكان مجلس إملاء أو وعظ أو تذكير أو غير ذلك في منازلهم او بيوتهم(r؟r).

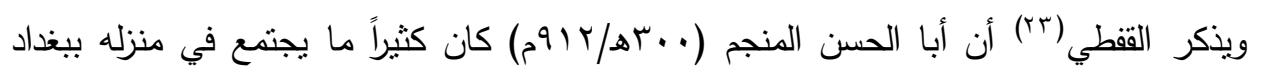

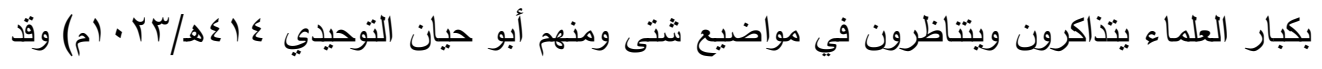
ألف أبو حيان كتابه الأمتاع والمؤانسة على أساس هذه المجالس، وكانت دار الامام الغزالي هـ 0هـ/1 1 ( م) مرتاداً للعلماء والطلاب ببغداد، بعد أن اعتزل وعكف على تأليف كتاب إحياء علوم

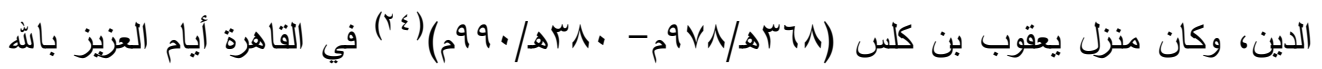


العدد الثاني والأربعون

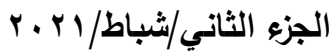

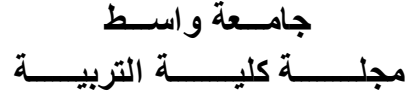

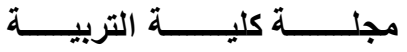

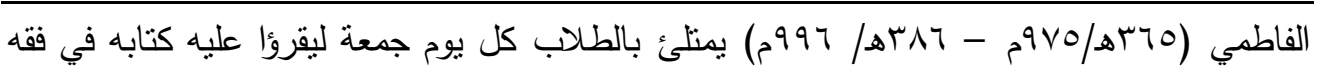
الإسماعيلية وغيرها (ro).

أما المجالس العلمية الأخرى عند اسطوانات المسجد فهي التي كانت تقود الحركة الأساسية في ثقافة المدينة اذ لم يخلو منها جامع في مدينة، بل في قرية أيضاً، ولها آدابها كما أن لها مكانتها الفكرية، ومواعيدها المقررة ومكانها المحدد (r؟). وقد تبلغ حلقة بعض العلماء عدة مئات من المستمعين كحلقة أبي علي القالي

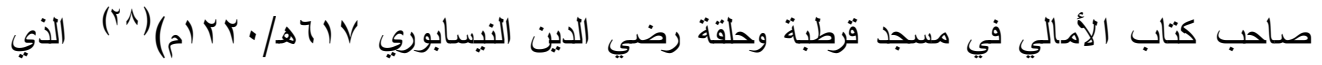
فاق على علماء عصره وعرف بأستاذ البشر وكانت حلقته في بخارى تضم أربعمائة من الطلاب والفضلاء بسبب اهنمامه فضلاً عن الإملاء بعقد المناظرات والحوار والمناقثة والاجتهاد بالرأي حتى بـى لهن

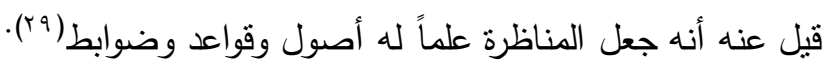
وكما خصبت المجالس في المادة تنوعت في العلوم وكان أهم مجالس العلماء ما يختص بالتقسير والحديث والفقه ولكنها كانت أيضاً للشعر والأدب والمنطق والطب أحياناً وثمة مجالس اللغوبين والنحويين والإخباريين (·r). وثمة نوع آخر من مجالس العلم هو الصالونات (المنتديات الثقافية) والمجالس لدى الخلفاء

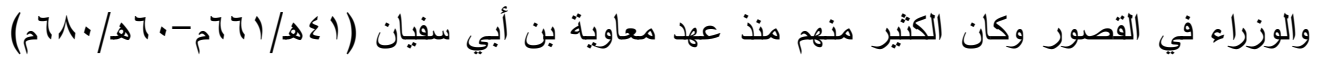


العلماء والأدباء والثعراء وأهل الفكر يبرزون فيه ما لديهم ويتتاظرون ('آن.

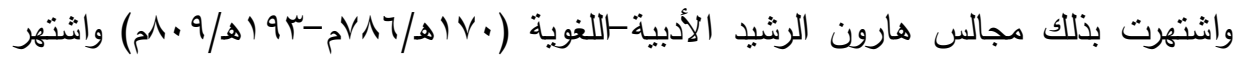
بيت الحكمة الذي أنشئ للترجمة وحفظ الكتب وقد رعاه بعد ذلك المأمون (191اهـ/rالمح1 1 اهـ/Trام) وزاد فيه واستقطبت الاهتمام مجالس المأمون الفلسفية وفي بعضها نشأت فكرة خلق

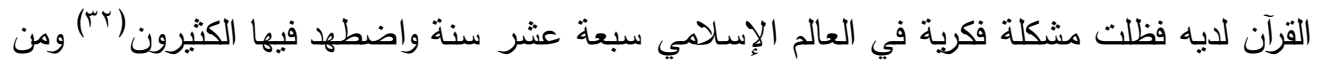
هذه المجالس ما كان يعقده الوزراء أمثال الوزير ابن الفرات أبي الفضل جعفر) اوسهـ/. . . (م) وقد

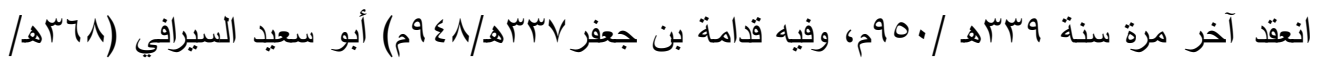

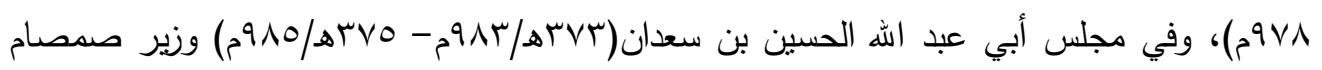

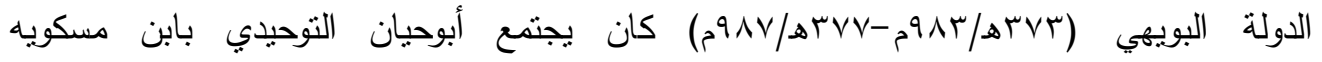

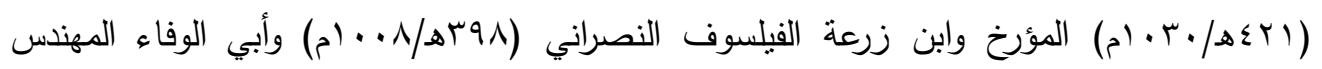

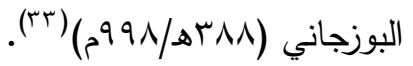


العدد الثاني والأربعون

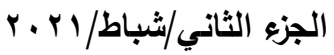

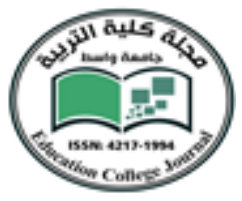

وبديهي أن هذه المجالس العلمية لم تكن مشابهة، ولا كانت في علم واحد، فقد كانت ثمة آلاف منها بكل صقع، ولهذا تعددت نوعهاً وكمها وكيفيتها، وعليها إقبال عظيم لأنها تعطي للطالب فرصة ولة ولتهات

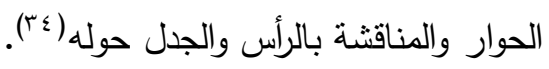
r - r منشآت التصوف:

... تعتبر منشآت التصوف من خانقات وزوايا وأربطة من أهم المؤسسات الدينية التي توافق ظهورها مع ظهور المدارس(ro). وقد مر التصوف الإسلامي بعدة مراحل تطور مختلفة بدأت من من فئن مظهر الزهد والتقشف في عهد الرسول (صل الله عليه واله وسلم) الخلفاء الراشدين إلى مظهر ترك الحياة الدنيا والتقرغ للعبادة الفردية في العصر الأموي، وهو مظهر زاد من حدته الغبن والجور اللذين أصسابا كثيراً من العامة نتيجة تحول الخلافة إلى ملك عضوض في هذا العصر، واستغلال الثروة

والمال من جانب الخلفاء في مظاهر الترف والرفاهية على حساب الفئات البسيطة من المجتمع (بr). وقد اشتث هذا التيار قوة في عهر العباسبين وبدأت ظاهرة التعدد والتتظيم الجماعي لفئات

المتصوفة، ودخلت الدولة في صراع معهم تحت تحريض الفقهاء(rv).

وازداد عدد المتصوفة في مدن العراق والثام ومصر وفي مدن الأندلس، والسبب في ذلك ردة

الفعل على مظالم الحياة العامة ورفضهم لها(r^). وإذا جرب بعض الفرق الجواب عليها بالثورة كما فعل القرامطة(ª) وبعض الخوارج فأن الصوفية ردوا عليهم بالانسحاب من الحياة والاعتكاف والخلوة مع الله(•؟). وقد أنشأت لهم مبان خاصة بهم يختلون فيها للعبادة ويقيمون فيها إقامة تامة أطلق عليها

. الخانقات

وكانت كل خانقاه وحدة قائمة بذاتها في داخلها غرف الخلوات وفيها حمام ومطبخ وفي بعضها خزائن للأدوية وقد يخصص لها طبيب، وللصوفية آداب في الخانقاه واجتماعات أسبوعية ونظام صارم في الزيارات والغياب والطعام، ولكل منهم سجادته ولكنهم لا يتحركوا إلى شيء إلا بأمر الثيخ ولا يقبلون زائراً إلا بعد اختياره وربط النساء كانت أشد صرامة في الملبس والسلوك( (1). ومع شيوع وانتشار التصوف الذي خالطته الأغراض المادية أنشئت الرُّبط) كمبانٍ للمتصوفة الذين يريدون أن يقضوا بقية حياتهم متفرغين للعبادة والصلاة دون أن يرتقوا في درجات التصوف المختلفة التي كانت في الخانقات، أي أنها كانت بمثابة الملاجئ التي يأوي إليها العجزة والبطالون الذين ليس لهم دخل يعيشون منه حياة راضية متفرغين للعبادة(r). 
العدد الثاني والأربعون

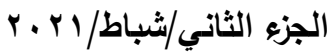
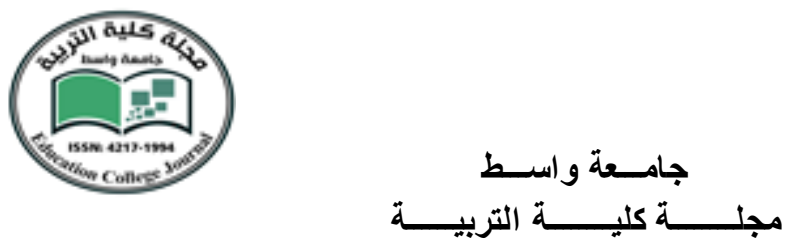

وقد ساهمت هذه المنشآت بما تشتنل عليه من وحدات معمارية أخرى تستخدم كمرافق عامة كالميضآت والأسبلة والكتاتيب والمكتبات ووحدات سكنية في توفير خدمات عامة للقاطنين في المدينة الإسـلامية والواردين إليها (r؟).

وكان لكل منشأة من هذه المنشآت جهازها الإداري المستقل المسؤول عن إدارتها ورعاية أمورها، سواء كان جباية ريع أوقافها وحرفة حسب ما تحدده وثيقة الوقف أم مباشرة ما يتعلق بأداء وظائفها من صلاة وتدريس وتصوف، وكلفت الدولة بسلطاتها القضائية والتتفيذية رعاية هذه المنشآت من خلال ديوان الأوقاف الذي يختص بشؤونها ورعاية مصالحها، فاستمرت في أداء وظيفتها

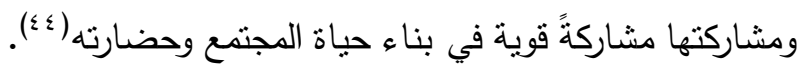
ومما سبق يتضح لنا أن المؤسسات الدينية الإسلامية لكل منها ما هو عام الارتفاق لكل المسلمين كالمساجد، والمساجد الجامعة، ومنها ما كان عام الارتفاق في حدود شروط الوقف التي ربما تحدد نظاما للارتفاق كالخانقات والزوايا والربط وغيرها(0)؛ وكان.

\section{المؤسسات الثقافية:}

المدارس:

... المدرسة لغةً لفظ مشنق عند العرب، من الفعل درس، للفعل درس معانٍ عديدة فهو يأتي

$$
\text { بمعنى قرأ، ودرسوا ما فيه، أي قرأوا ما فيه. }
$$

وقد جاء في المعاجم العربية، أن المدرسة موضع الدرس والجمع مداريس( (َ؛).

أما المدرسة بمعناها الاصطلاحي: هي الأكنة التي كانت تشاد لاقراء القرآن وتلاوة آي الذكر مر

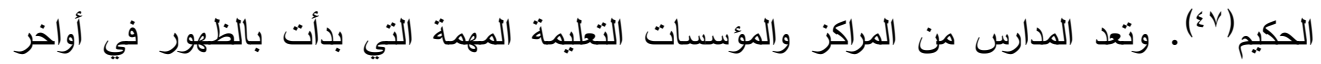
القرن الثالث الهجري/التاسع الميلادي وبداية القرن الرابع الهجري/العاشر الميلادي (^ء) فبعد أن للمساجد الدور الرئيس والأساس في عقد الحلقات العلمية وإجراء المناظرات فيها، أصبحت المدارس التي كانت ظهورها نتيجة حتمية للنطور العلمي الحاصل في المدن الإسلامية. فضلاً عن تزايد أعداد الطلاب الذين يرتادون المساجد لتلقي العلوم، ولكثرة الحلقات الدراسية فيه وما يحدث فيها من مناظرات ونزاعات واختلافات في الرأي ومن أسئلة ومناقنات كانت تؤدي إلى يلى إحداث ضجيج كبير في المسجد، فدعى ذلك كله إلى إيجاد مراكز تعليمية مستقلة ومخصصة للتعليم فقط ألا وهي المدارس(ج)؛ 
العدد الثاني والأربعون

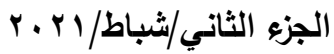

وما أن حل القرن الخامس الهجري الحادي عشر الميلادي حتى بدأ نوع آخر من المدارس

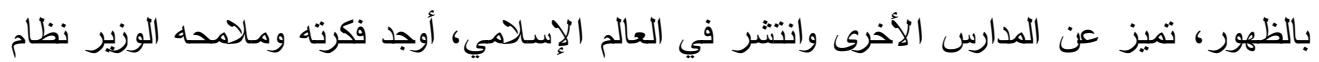


تسمى بالنظاميات (10 (0). وقد أخذت الددارس طابعاً مشتركاً فكانت متشابهة التخطيط والبناء في العالم الإسلامي كله،

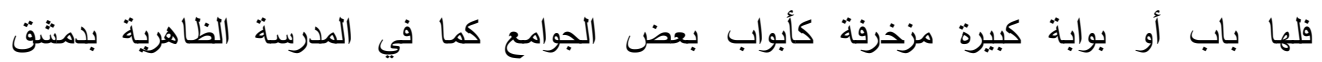

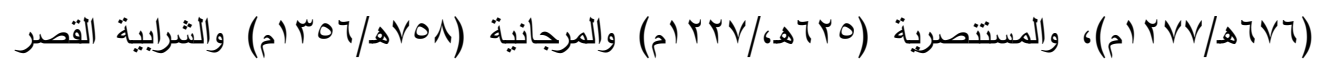

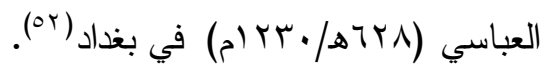
ثم ساحة تعرف بالصحن تحيط بها الحجرات في طابقين على الأغلب لإيواء الطلبة والمدرسين

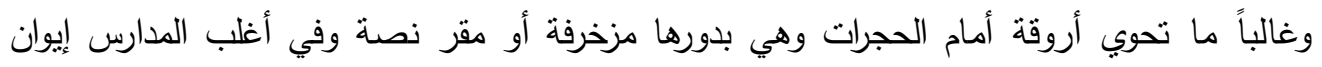

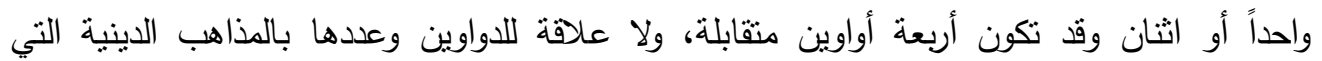

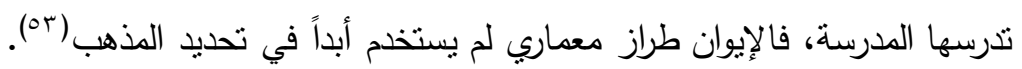

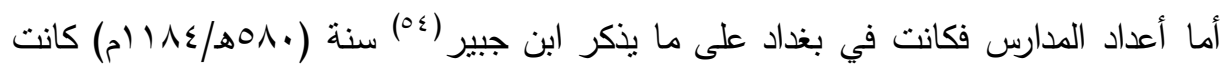

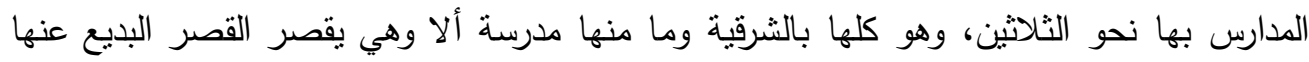
وأعظمها وأثهرها النظامية.

ولهذه المدارس أوقاف عظيمة وعقارات رحبة تصير إلى الفقهاء والمدرسين بها ويجرون بها

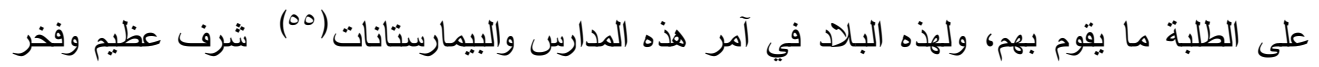
مخلد (07).

والواقع أن مدارس بغداد تجاوزت الثثاثثن وكانت عند سقوط المدينة بيد المغول ثمانية وثثلاثين

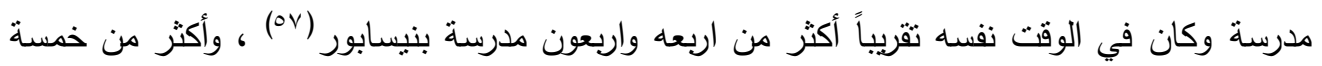

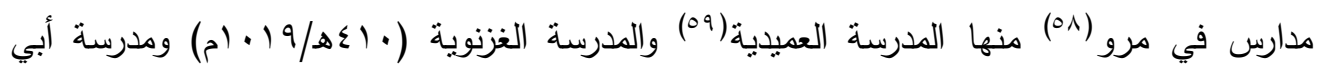

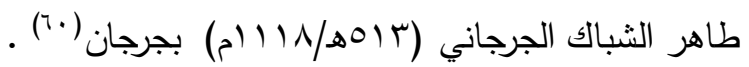
ويذكر المقريزي( (7) أنه كان في دلهي بالهيند من المدارس الإسلامية ما عدته ألف مدرسة كلها للحنفية إلا واحداً للشافعية. وقد وصلت هذه المدارس إلى أرقى المسنوى من التنظيم والإدارة والمستوى العلمي الذي والي

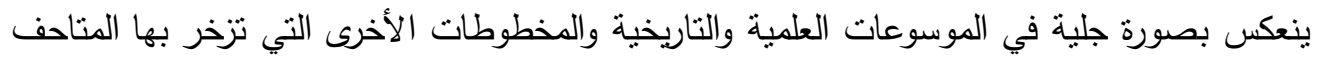


العدد الثاني والأربعون

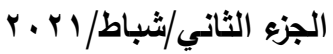

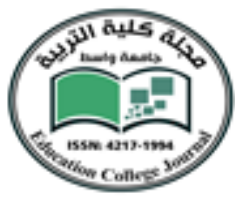

والمكتبات العالمية وأرست هذه المدارس نظام وتقاليد علمية راسخة تأثرت بها واتبعتها الجامعات

$$
\text { الأوربية ومازالت مستمرة حتى الآن (rا)). }
$$

وساعد نظام الوقف(rآ) مساعدة بالغة على إنشاء هذه المؤسسات باعتبارها منشآت موقوفة، وعلى استمرارها في أداء وظيفتها باستمرار الأوقاف الموقوفة عليها، من أرض وعقار كانت في باء الغالب منشآت مدنية كالمقصورات والوكالات والرباع والحوانيت وغيرها من المسققات التي كان يهتم بعماراتها ليستمر توارد ريعها للصرف منه على المؤسسات الدينية والثقافية الموقوفة(ء ؟) واهتم أيضاً باستخلال فائض الريع في شراء وإنشاء مبان أخرى تزيد الأوقاف وتتميها، كل ذلك انعكس بصورة أو بأخرى على المظهر المادي للمدينة الإسادية من عصر السلاجقة حتى العصر العثماني(70). r - ب المكتبات وخزائن الكتب:

تعد المكتبات وخزائن الكتب من المؤسسات التعليمية المهمة التي تساعد طلاب العلم والعلماء على حد سواء في الاستزادة من بحور العلم والمعرفة، فهي تهيئ للباحثين والدارسين سبل العلم والمعرفة، ولذلك فقد أكثر مؤسسوا المدارس من إيقاف الكتب فيها وبشتى الأنواع والعلوم والفنون(77). ولأهمية هذه المؤسسات فقد عمل مؤسسوها على إنشاء المباني الخاصة لها وتعيين النظار والمشرفين عليها فقد كان لكل خزينة من خزائن الكتب شخص أمين عليها أو خازن لها أو شاهد

وقد اختلفت طرائق الإعارة في هذه الخزائن من مدينة لأخرى، فقد كانت هناك ضوابط للإعارة كما يصفها ابن خلدون(^^) بقوله: (لا يجوز إعارة الكتاب إعارة خارجية إلا إذا كان المستعير شخصاً موثوقاً به وأميناً، على أن يدفع ضماناً هاماً وأن يرد الكتاب مدة لا تتجاوز الثهرين). غير أن المكتبات لم تظهر بشكل واسع، ولم تتسع الكتب نفسها إلا منذ القرن الثالث الهجري

التاسع الميلادي بعد انتشار الورق وكان امتلاك مكتبة في أي منزل علامة ارستقراطية وغنية(79). والرواة للحديث النبوي ولأخبار العرب والشعر هم الذين اهتموا بأن تكون لهم مكتباتهم الخاصة لأنها من صناعتهم وهي تكبر وتصغر حسب مبلغهم من الغنى، وقد يبيع بعضهم كتابه من الفقر،

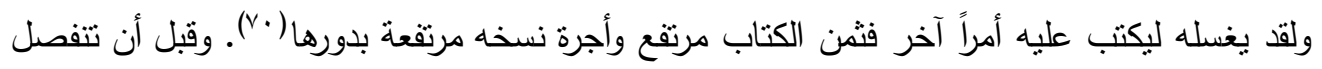

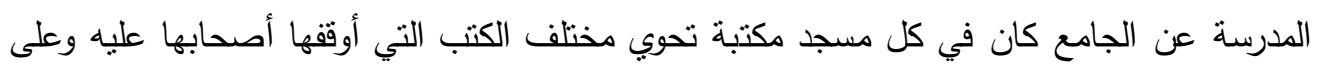
رأسها نسخ عددية من القرآن الكريم يقرأ فيها الناس فلما انفصلت المدرسة لم تختفي مكتبات المساجد في المدن ولكنها تضاءلت عدداً واقتصر معظمها على نسخ القرآن الكربم وعلى الكتب الدينية فقط (v) 
العدد الثاني والأربعون

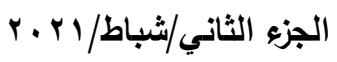

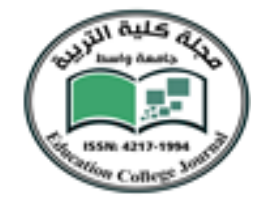

\section{جامسـعة واســ}

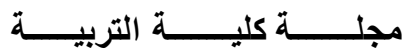

وكانت المكتبات قد تكونت في جميع المدن العربية الإسلامية وكان النسّاخ والوراقون قد أصبحوا

صناعة هامة في المجنمع الإسلامي، فعلى اساس المكتبة بنى بقاء العلم الإسلامي وتتاقله (Vr).

ولهذا وجدت في المدن الإسلامية أنواع من المكتبات هي التي احتفظت بالتراث العربي الإسلاهي (Vr) ويمكن أن نصنفها إلى:- وجن

أ - المكتبات العامة.

ب - المكتبات الخاصة.

ج- مكتبات المدارس.

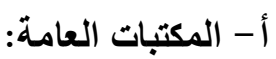

ونقصد بها المفتوحة للرواد، والواقع أن معظمها كان نصف مدرسة تؤدي الطلاب وترزقهم الأجور ولم يكن يرتادها إلا فئة محدودة هي العلماء والطلاب الباحثون فهي مؤسسات لخدتهم، كما أنها على أي حال قليلة العدد في المدن وتقوم على الوقف ومنها دار الحكمة الذي أنثأها الرشيد في

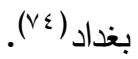

ولم يكن الورق قد انتشر كثيراً بعد فكانت للتراجم والنساخين ولمن يود الإطلاع على علوم الأوائل ونسخ الترجمات، وقد زادها المأمون مجموعات أخرى من الكتب ثم زاد الخلفاء العباسيون من بعد فكانت طوال العصر العباسي مجمعاً للعماء طوال العصر العباسي مجمعاً للعلماء والباحثين

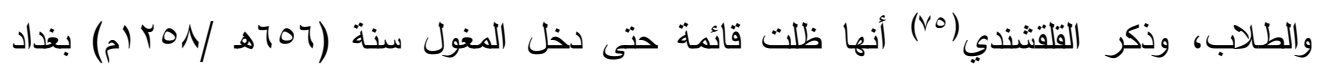
فاندثرت مع ما أندثر. ب - المكتبات الخاصة: وتشمل المكتبات التي يؤسسها السلاطين والحكام والأمراء العلماء والأدباء، وهي بدورها كثيرة جداً، وأولها مكتبات الخلفاء سواء منهم الأمويين أم العباسيون أم الفاطميون، ومن الأمثلة مكتبة الخلفاء الأموبين في قصر الخضراء بدمشق (TV). وقد أخرج عمر بن عبد العزيز رضي الله عنه (IV9 الطب استخار أربعين يوماً قبل أن يدفعه للناس وقد دخل المقدسي(YV) خزانة الكتب في دار عضد

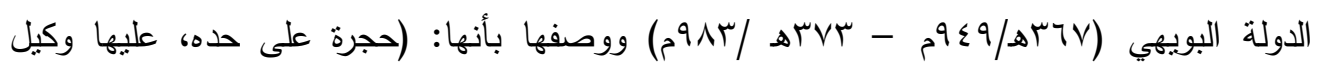
وخازن مشرف من عدول البلد، ولم ييق كتاب صنف إلى وقت عضد الدولة من أنواع العلوم إلا وحصله فيها، وهي أزج طويل في صفة كبيرة فيه خزائن في كل وجه، وقد ألصق إلى جميع حيطان الأزج والخزائن بيوناً طولها قامة في عرض ثناث أذرع من الخشب المزوق عليها أبواب تتحدر من 
العدد الثاني والأربعون

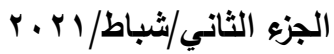

فوق، والدفاتر منضدة على الرفوف لكل نوع بيوت وفهرسات فيها أسامي الكتب ولا يدخلها إلا كل

ولم تكن المكتبات الخاصة حكراً على الخلفاء فقد كان في كل مدينة أكثر من سري بارز لديه

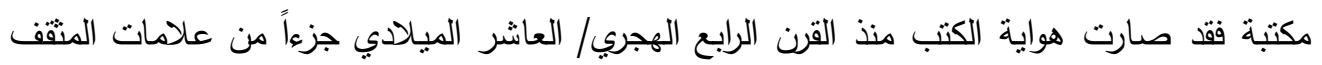
ومن زينة البيوت وأثاثها( (V^). ج- مكتبات المدارس:

وكانت جزء مهم من أجزاء المكتبات وخزائن الكتب، فجميع مدارس العالم الإسـاهي حوت المكتبات التي يرجع إليها المدرس والطالب(va). فالمدرسة النظامية ببغداد اشتهرت بمكتبتها شهرتها بمدرسيها وكان مجتمع نوادر الكتب، فقد ذكر ابن الجوزي( (^) أنها سنة آلاف.

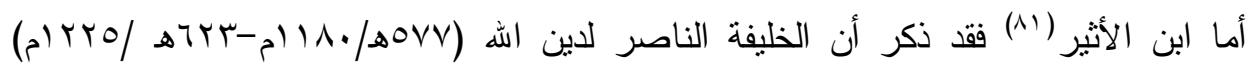
أمر بعمارة خزائنها ونقل إليها من الكتب الفنية ألوفاً لا يوجد منلها وكان للمدرسة المستتصرية ببغداد مكتبة غنية منظمة نقل إليها يوم افتتاحها ما حمله مائة وستون جملاً وأن عدد هذه الكتب بلغ ثمانين ألف مجلد. ومعظم هذه المكتبات كانت منظمة ولاسيما الكبيرة منها فكانت لها خزائن تصف فيها الكتب بعضها فوق بعض ولها فهارسها، ولكل علم أو فن خزانة ومكانة من الفهرس وقد أمر بوضع فهرس

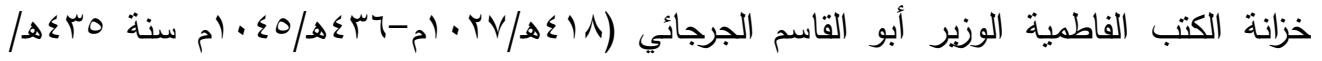

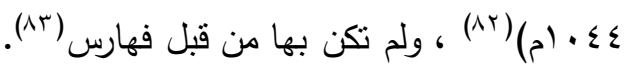
ومن جملة التتظيم كان لكل مكتبة كبيرة مشرف أو قيم من أهل الدين والورع، هو الخازن وهناك

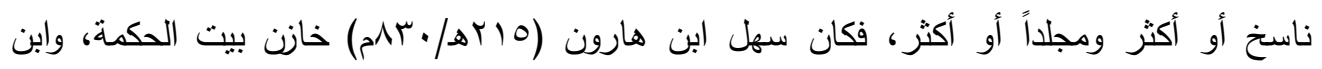
مسكويه خازن مكتبة ابن العميد، كما كان لكل مكتبة في عصر الترجمة ويكون خزائن الكتب

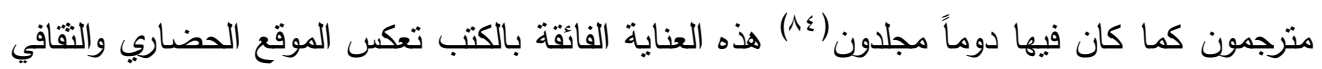
للأداة الثقافية الأولى في المجنمع الإسلامي. ولأهمية هذه المؤسسات ودورها الحيوي في المسيرة التعليمية، فقد أسهمت الأوقاف إلى حد كبير الإسير في تحفيز النشاط الثقافي لهذه المؤسسات إذ أنها لما وفرته من أسباب استفادة طلاب العلم وشيوخهم من وقف المكتبات العامرة بأمهات الكتب الأصلية ونفائسها، فقد أوقف الكثير من خزائن كتبهر وما 
العدد الثاني والأربعون

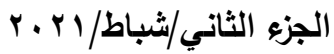

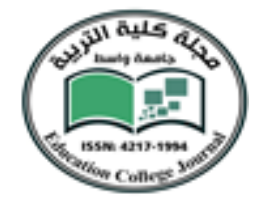

للديهم من مؤلفات ونتاجات علمية خلال رحلاتهم العلمية المفعمة بالنشاط الثقافي، يكلفون بذلك

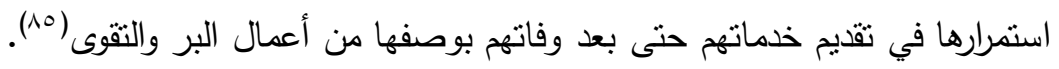

$$
\text { ب - الإضاءة في المدينة: }
$$

... عرف العرب قبل الإسـلام جمع وسائل وطرق الإضاءة المعروفة ولاسيما أولئك الذين كانون يعيشون منهم على أطراف الجزيرة العربية في اليمن والإحساء والبحرين والحجاز أو في مشارف الثنام وحافة السواد العراقي (1^). وكان أكثرها شيوعاً وسائل الإنارة بالزيوت ثم بالشموع، وقد يكونوا قد عرفوا نوعاً من الإنارة بالنفط الذي استخدمه الساسانيون(Av) على حوافي العراق أما النار المطلقة فكانت لسكان البادية وقد باند يوقدونها لعقد الأحلاف ولاستدعاء النجدات عند الحرب أو للسمر في الليل، وقد كانت النار على أي حال أساس كل عمليات الإضـاءة وكان يستخدم فيها سعف النخيل(^^). ولم يزد العهد الإسلامي شيئًاً عن مواد الإضاءة الثلاث الزبت والثمع والنفط، ولكنه تفنن في إخراج الوسائل التي تحتضنها والأدوات التي تبرز بها النار وتحمل من مكان لآخر.

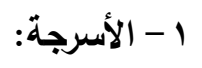

كانت هي الثائعة في العالم الإسلامي، هي ليست أكثر من وعاء فيه زيت وله فنتي، وزيت الزيتون منوفر في أنحاء المملكة الإسلامية في الأندلس وأفريقيا والثام وفارس، وكان السراج في أول

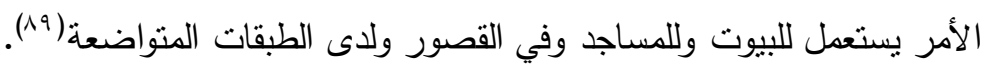
وتساوى في استخدام السراج للإضاءة الخلفاء والعامة وكان الفرق فقط في نوع السراج من الطين أو الزجاج أو الخزف أو خلائط النحاس، وفي الكبر والصغر وفي الزخرفة الذي تقع عليه(·و). وقد استخدم في العهذ الأموي والعباسي على السواء حتى العهد الفاطمي والمملوكي. وكان السلطان هو الذي يتكفل بإضاءة المساجد والمؤسسات من مدارس وزوايا وربط ودور

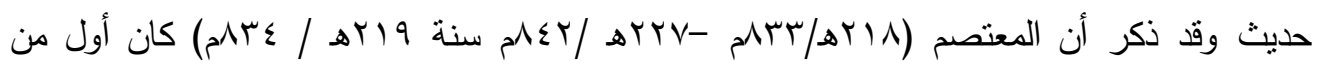
أنفط وأسرج بيت المأزمين في طريق عرفة... وتلألأت الأنوار في الحرم المكي والمسجد النبوي خيفة أن يعدوا اللصوص على المعتمرين فهي مطردة للشيطان ومذبة للهوام ومدلة على اللصوص ولى (19) وأما القناديل أو المصابيح) فكانت خطوة منقدمة على السراج أنها ببساطة طريقة لإضافة الزجاج الثفاف حول ذيالة السراج ثم تعليقه إن شاء حامله يدل إثباته الدائم على قاعدة، وقد كانت القناديل معروفة منذ القم، ولكنها لم تكن مبذولة للناس بسبب تكاليفها فاختصت بها دور العبادة بالذات، كما حملت للكبراء والموسرين في سراهم ليلاً بالشوارع ووضعت على أبوابهم. 
العدد الثاني والأربعون

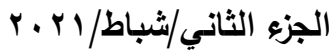

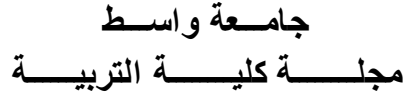

وتذكر المصادر التاريخية أن المأمون الخليفة العباسي أمر بالاستكثار من المصابيح في

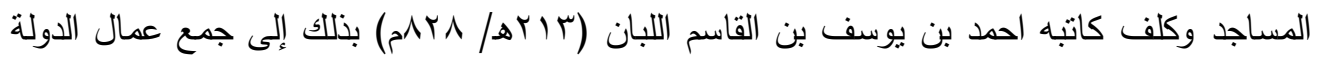

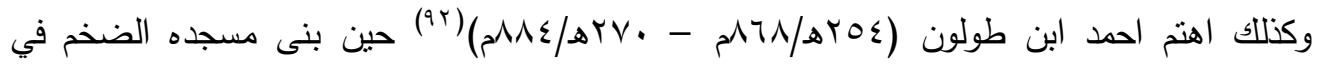
القطائع أن يضيئه فعلق بسقفه السلاسل النحاسية المفرغة والقناديل المحكمة(بهونه. وقد تطورت صناعة القناديل جداً في العهد الإسلامي فإذا كانوا قد جمعوا بعض الأسرجة إلى بعضها فقد كان إمكان جمع القناديل أوسع بسبب ما بمسكها من المعادن ولأنها على الأغلب ثابتة

معلقة.

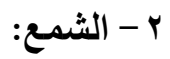

كان في استخدام الثمع في الإضاءة نوعاً من التزف لارتقاع ثمنه ولاعتياد الناس على تقديمه، أو حمله في المواكب والاحتقالات، وكان يباع بالوزن واشتهرت أصبهان (ء9) بإنتاجه وكانت تحمل في ولي جملة خراجها السنوي إلى السلطان ألف رطل منه وب( وكان للشموع أنوار كالمصابيح والقناديل تجمعها مجموعة في إطار واحداً واثثين أو ثناثة وتثبت الشموع فيها بأشواك أو بركائز ويمكن في هذه الحالة تعليقها في المعابد وغرف القصور • أما الثموع المحمولة فكانت تحتاج الثماعد التي تمتذ من الوعاء الصغير الذي يحمل شمعة واحدة إلى القاعة ذات الفروع المتعدة وتصنع الثماعد من الحديد والنحاس والبرونز والذهب والفضة

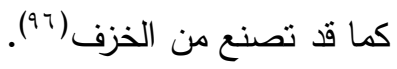
وكانت الإضاءة بالشموع منوفرة وممكنة وبخاصة لذوي البسطة واليسار ولكنها كانت هناك شموع مكلفة ومن أمثلنها الثموع العنبرية وهي الممزوجة بمادة العنبر حيث أنها تملأ المكان برائحة العنبر الفواح عندما تضاء. والثموع الكافورية وهي غالية الثن بسبب مزجها بالكافور ورائحتها



وشموع العنبر والكافور كانت تختص بالاحتفالات الكبرى كأعراس الملوك والوزراء وهي التي

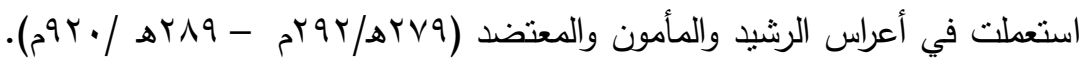
فأوقد الرشيد لزبيدة شموع العنبر ، وأوقد المأمون في عرس بوران بنت الحسن بن سهل شمعة شهن عنبر فيها اربعون مناً في تور من الذهب وزاد المعتضد حين تزوج بقطر الندى (اسماء بنت خمارويه

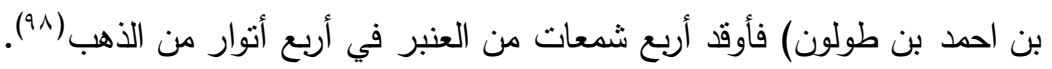
وثمة أنواع أخرى من الثموع كالموكبية وتكوين طويلة ثخينة القطر وقد تحمل على العجل، والفانوسية وهي صغيرة للفوانيس، والثثلاتية المنلثة الذبالة والطوافة التي يطاف بها في البيت (9 (9) . 
العدد الثاني والأربعون

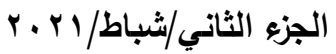

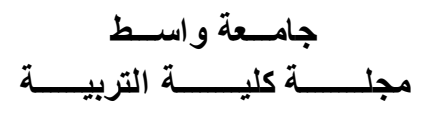

وقد كانت للمصابيح والثموع خدم في القصور أو قومة في المساجد يقومون على تنظيفها وصيانتها الدائمة وكانوا بصورة خاصة في العهد الفاطمي يتقاضون رواتبهر من السلطان.

أما في بغداد والمشرق وفي الأندلس فكان القاضي هو الذي يشرف على شؤون المساجد وشموعها ومصابيحها ونظافتها وقومتها وينفق على ذلك من أوقافها ('”.).

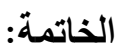

من خلص بحث المؤسسات العامة في المدينة الاسلامية توصلت إلى عدة نتائج ومن أهمها:ا-تميزت المدن الإسلامية بانتشار المؤسسات الدينية متمثلة بالمساجد ومنازل العلماء ومنشآت التصوف التي برز وجودها في المدن الإسلامية والفتوحات. ومنذ بداية الفتح العربي الإسلامي لها، فقد ابتتى العرب الفاتحين الكثير من المساجد في المدن الإسادية، وإلى جانب ذلك فقد كانت تعقد فيها الحلقات العلمية إلى جانب الثعائر الدينية التي تقام في المساجد، ولهذا دعت الحاجة إلى إيجاد مراكز أو مؤسسات تعليمية تكون مهنها هو الجانب العلمي لذلك فقد ظهرت المدارس، والمكتبات وغيرها... الخ. r - ساهمت المؤسسات الدينية والتعليمية إلى حد كبير في تحفيز النشاط الثقافي في المدن الإسلامية، إذ أنها ساهمت في إعانة طلاب العلم والعلماء على الاستزادة في طلب العلم، وذلك من خلال ما فالي وفرته لهم من المكتبات فكان بعضها ذات طابع عام يفتح ابوابه لكل الراغبين بالعلم بينما تمتع بعضها ببعض الخصوصية منل قصور الخلفاء ومنازل العلماء وخزائن الكتب لاستفادة أكبر عدد ممكن من بن بأن الطلبة، أو من خلال إنشاء بعض المدارس كوقف لخدة الطلاب والعلماء، كالمدرسة العميدية والنظامية وغيرها... الخ.

r - إن المؤسسات الدينية التعليمية وتتوع المجالس العلمية كان لها الأثر البالغ في رفد الحياة العلمية، وإعطاءها دفعة إلى الأمام. 
العدد الثاني والأربعون

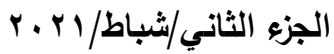

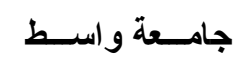

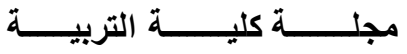

قائمة المصادر والمراجع

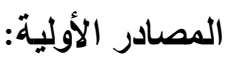

القرآن الكريم.

ا- ابن الأثير، أبو الحسن علي بن أبي الكرم ت.بآهـ/rسبام، الكامل في التاريخ، دار الكتب العلمية، بيروت، .5) 990

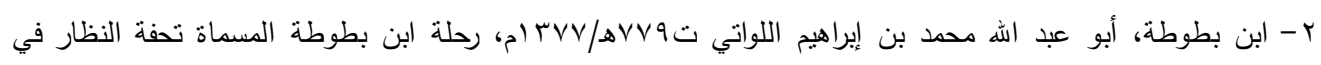

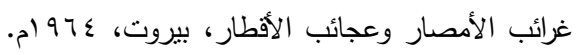

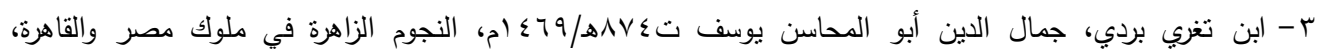

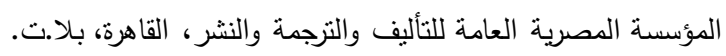

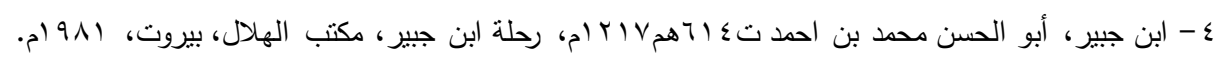



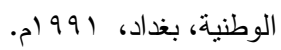

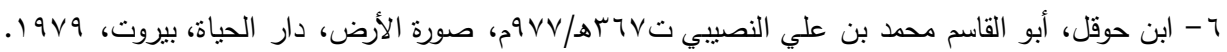

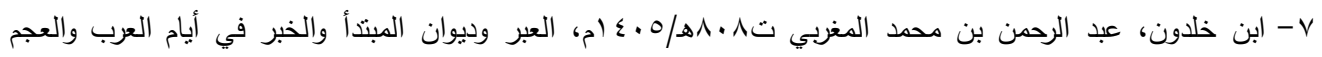

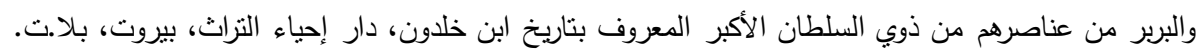
1 - مقدمة ابن خلدون، مطبعة دار العودة، بيروت، بلا.ت.

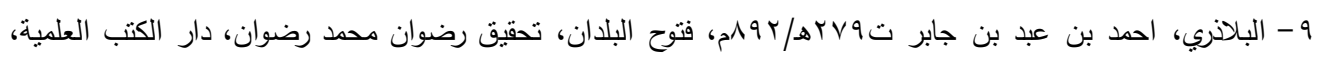

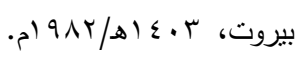

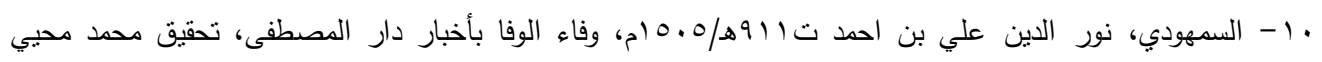

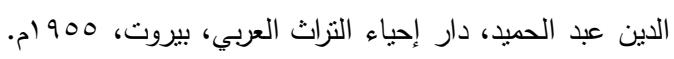

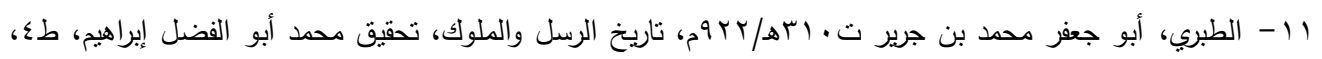

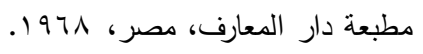

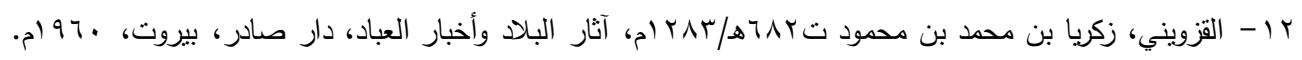

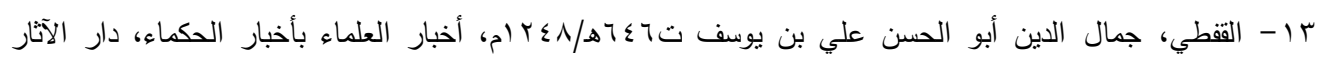

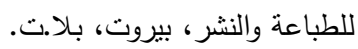

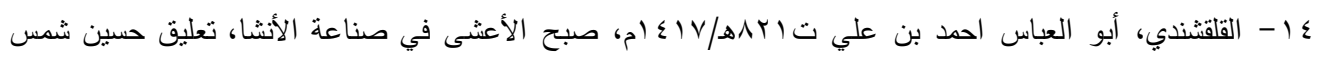

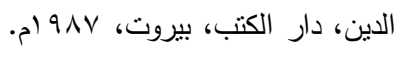

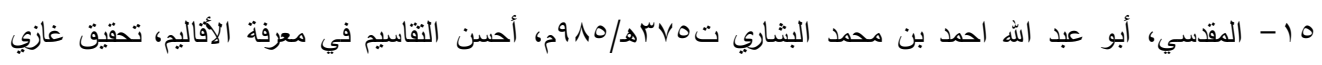
طلبمات، دمشق، بلا.ت.

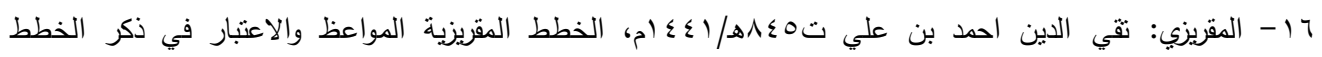

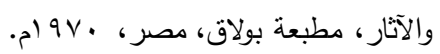

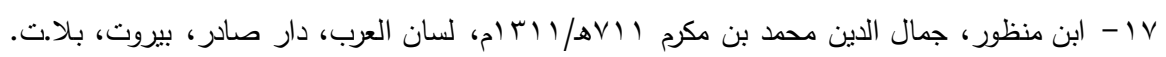


العدد الثاني والأربعون

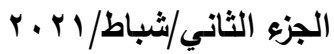

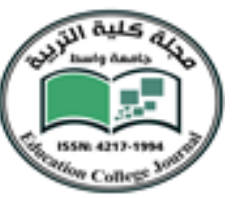

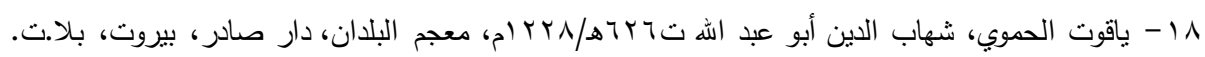

\section{المراجع الحديثة:}

ا - حسن، حسن إبراهيم، ناريخ الإسلامي السياسي والديني والثقافي والاجتماعي، طV، مكتبة النهضة المصرية، مصر، . $197 \varepsilon$

ץ- الرحيم، عبد الحسين مهدي، تاريخ الحضارة العربية الإسلامية، بلا.مط، بخداد، ؛ 99 ام.

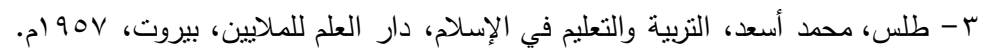

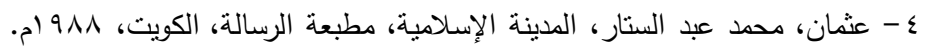

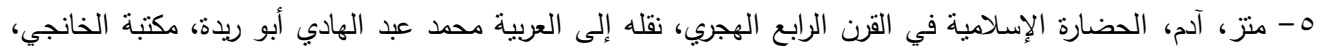

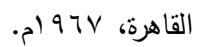
צ- مصطفى، شاكر، الدن في الإسلام حتى العصر العثماني، ذات السلاسل للطباعة والنشر والتوزيع، الكويت، .01911

V - معروف، ناجي، مدارس قبل النظامية، مطبعة المجمع العلمي العراقي، بغداد، س بV ام.

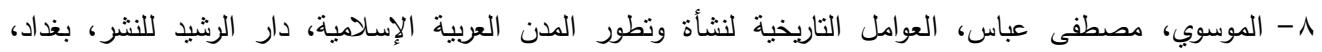
9 - ناجي، عبد الجبار ، دراسات في تاريخ الددن العربية الإسلامية، مطبعة جامعة البصرة، بلام، 919 ام. 
العدد الثاني والأربعون

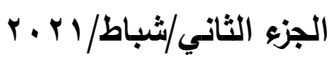

جامــعة واســ كلـ

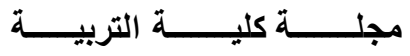

الهوامش:



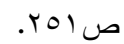

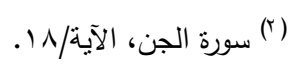

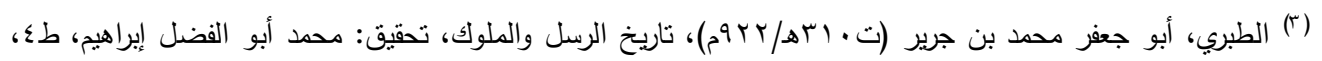

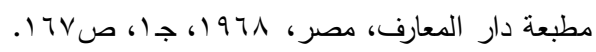

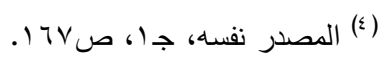

(0) حسن، حسن إبراهيم، تاريخ الإسلامي السياسي والديني والثقافي والاجتماعي، طV، مكتبة النهضة المصرية، مصر،



الموسوي، دصطفى عباس، العوامل التاريخية لنشأة وتطور المدن العربية الإسلامية، دار الرشيد للنشر، بغداد،

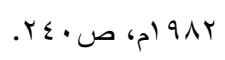

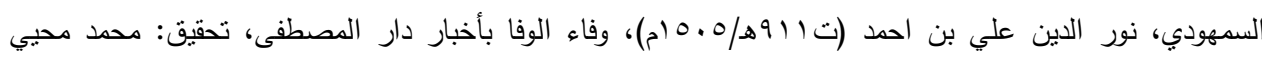

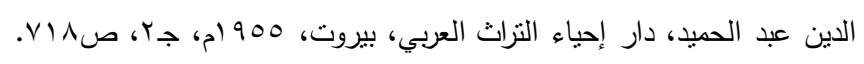

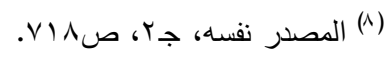

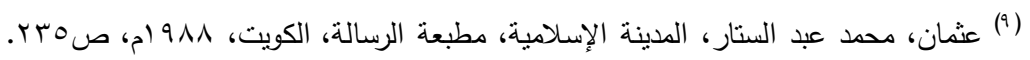

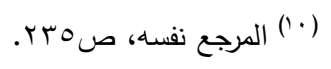

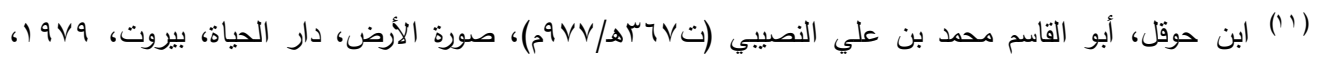

ص110.



$$
\text { ص }
$$

مصطفى، شاكر، المدن في الإسلام حتى العصر العثاني، ذات السلاسل للطباعة والنشر والتوزيع، الكويت،

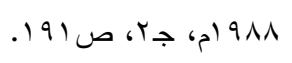

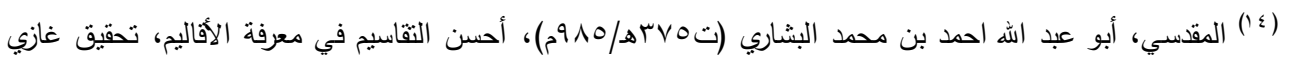

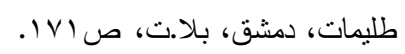

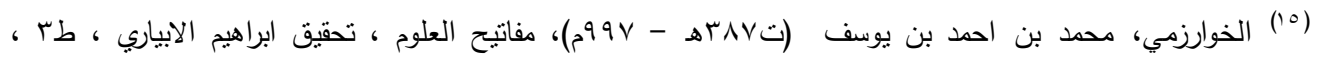

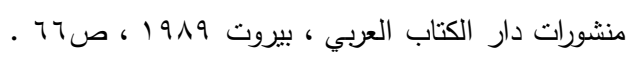

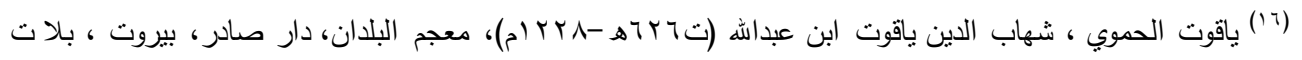

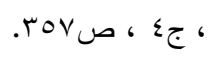

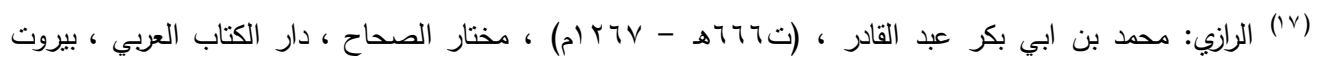

$$
\text { . IV (1978 }
$$

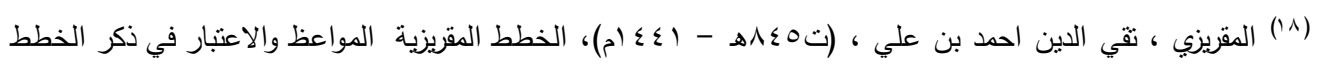

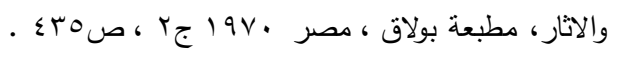


العدد الثاني والأربعون

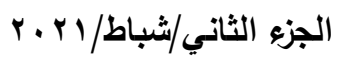

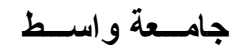

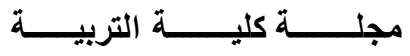

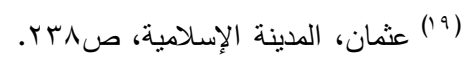

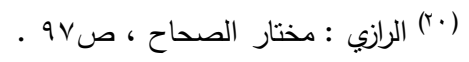

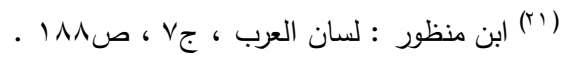

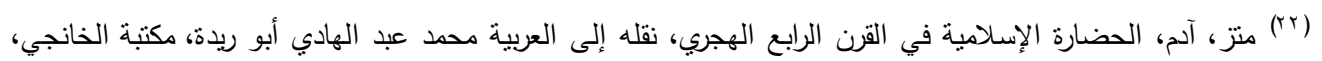

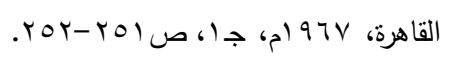

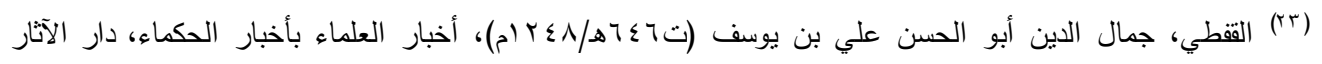

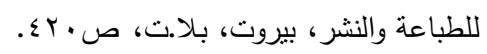

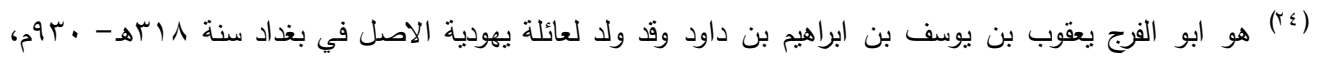

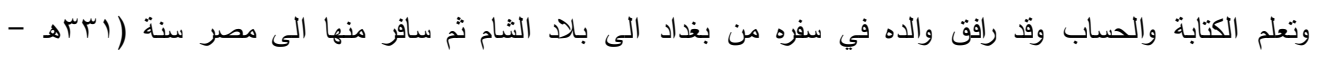

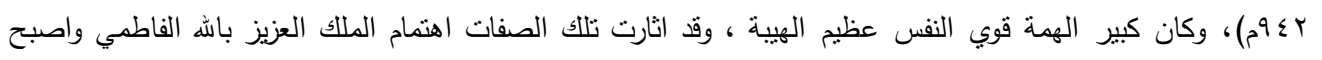

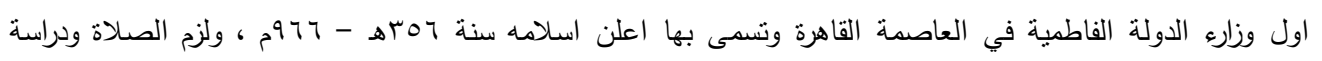

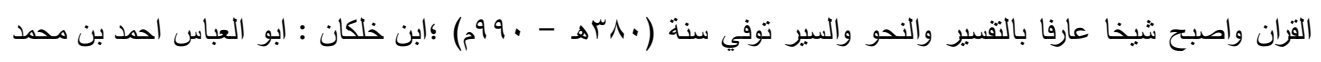



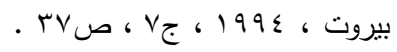



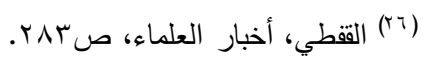

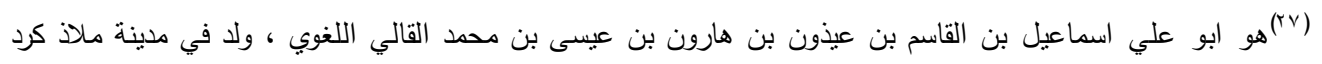



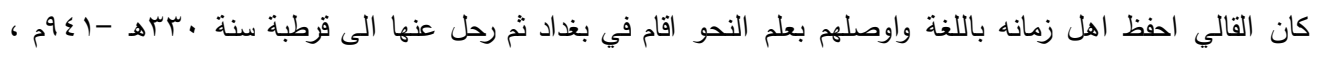



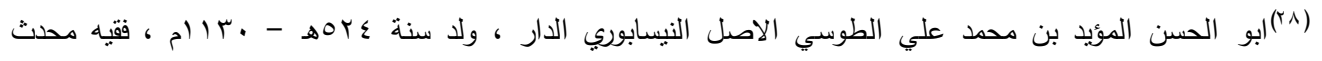

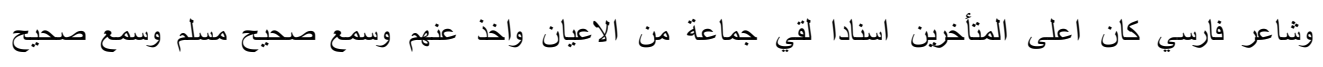
البخاري وسمع الموطأ وسمع تقسبر القران الكريم وسمع ايضا من جماعة من شيوخ نيسابور وذاع صيته واثتهر وتثرد



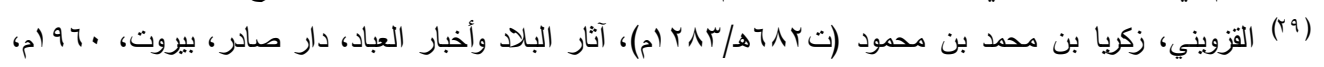

$$
\begin{aligned}
& \text { ص ص }
\end{aligned}
$$

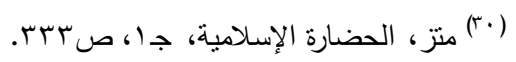

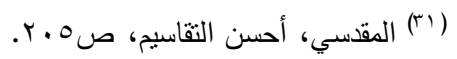

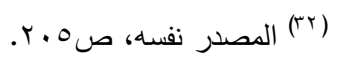

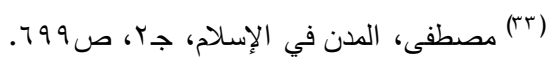

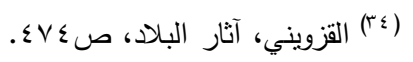

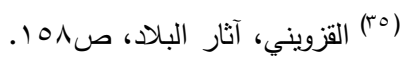


العدد الثاني والأربعون

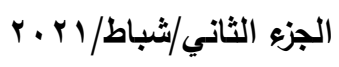



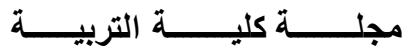

$$
\begin{aligned}
& \text { (דr) عثمان، المدينة الإسلامية، صس؟r. }
\end{aligned}
$$

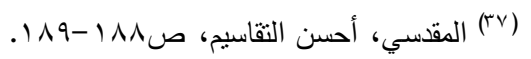

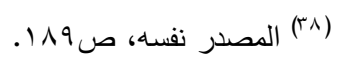

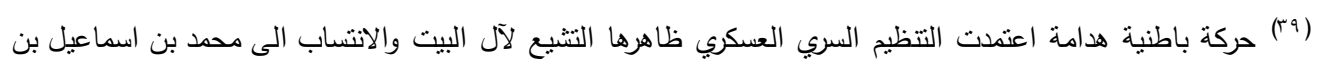

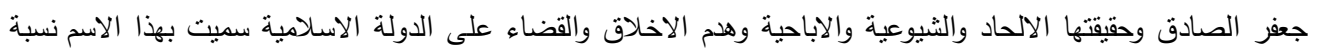



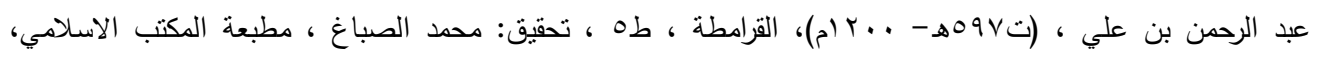

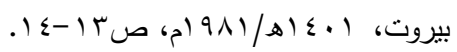

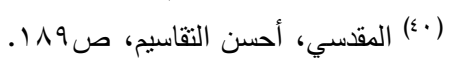

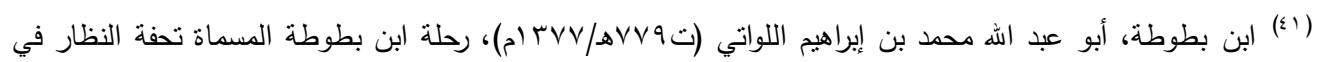

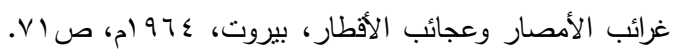

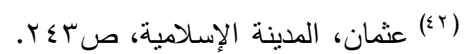

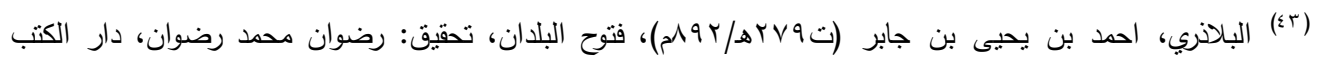

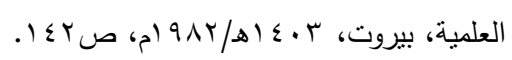

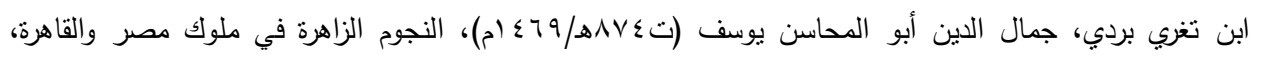

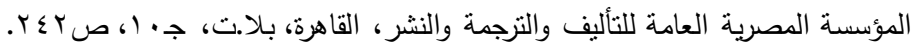

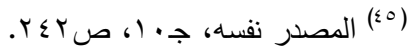

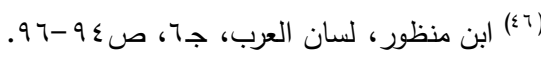

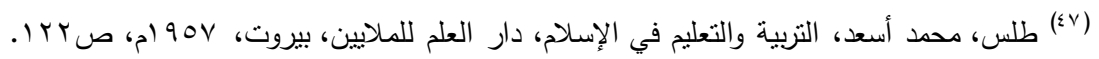

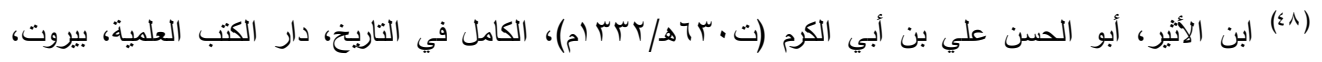

$$
\begin{aligned}
& \text { (990 } 990
\end{aligned}
$$

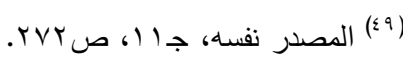

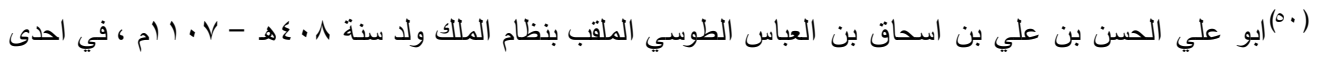

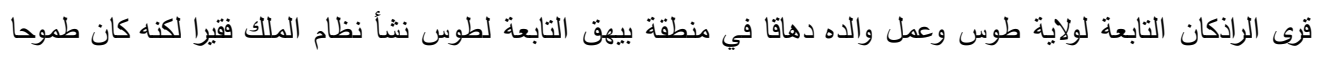

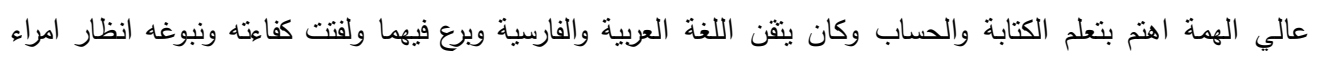

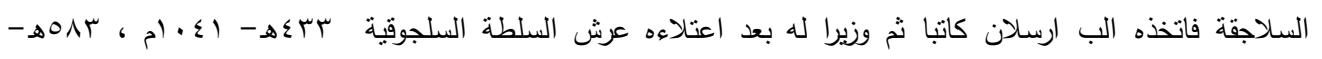

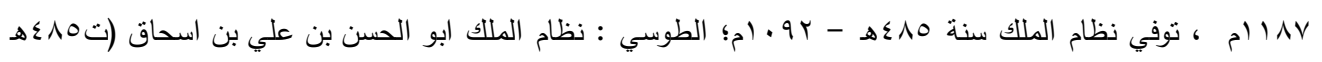

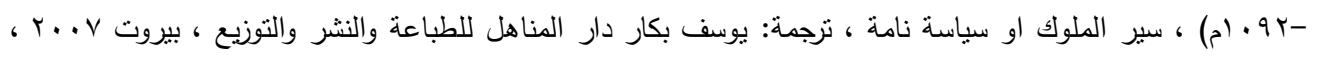

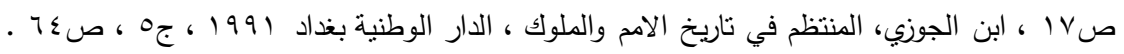

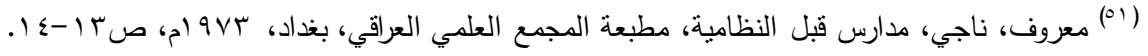

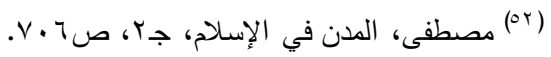

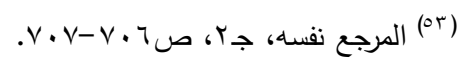


العدد الثاني والأربعون

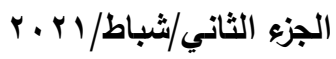

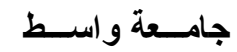

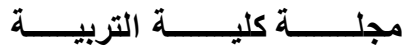



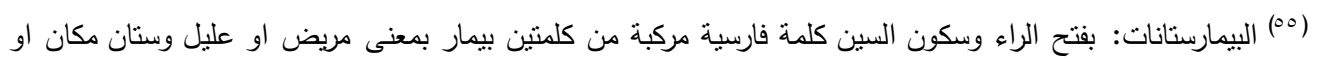

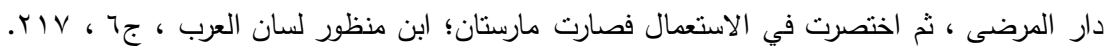

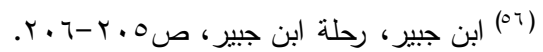

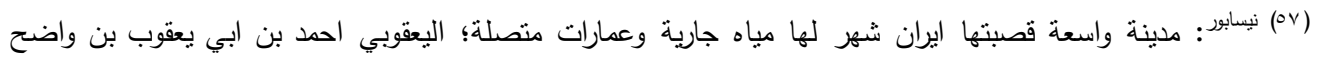

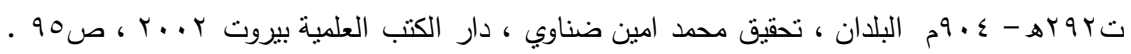

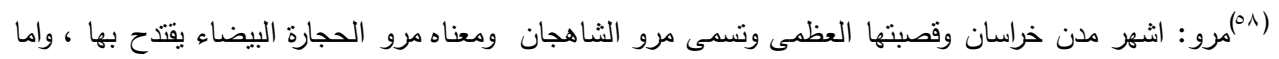



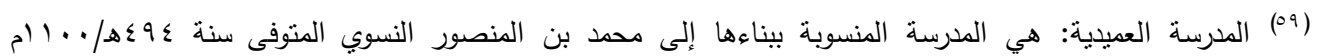

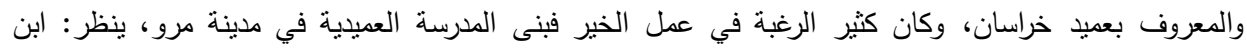

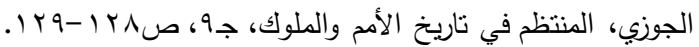

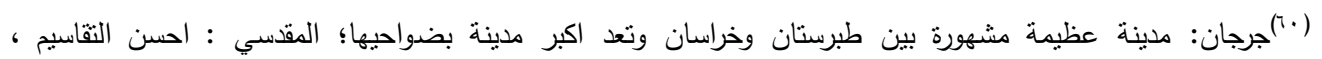
. ט

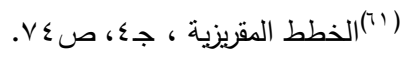
أ)

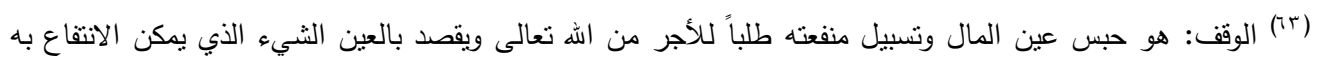

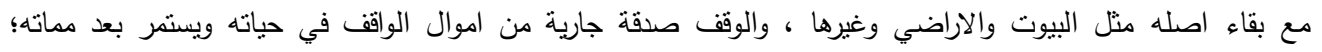

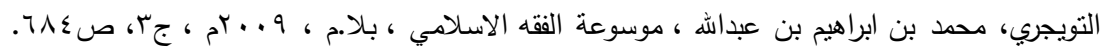



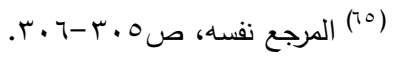

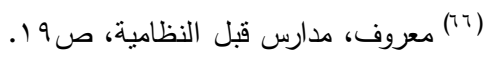

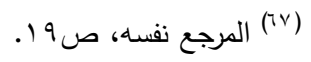

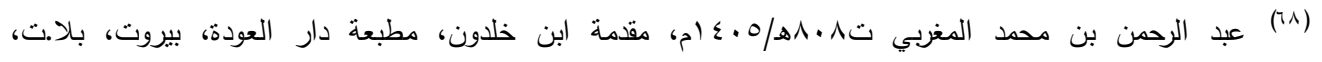

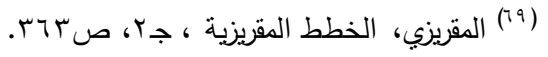

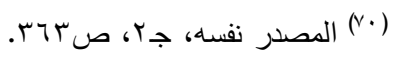

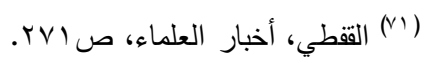

$$
\begin{aligned}
& \text { (Yr) }
\end{aligned}
$$

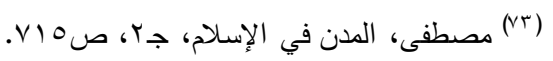

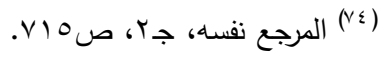

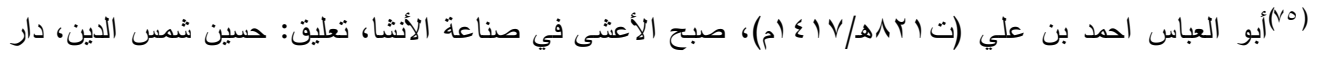

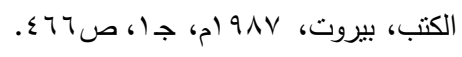


العدد الثاني والأربعون

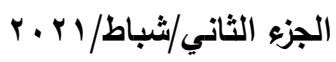

جامــعة واســ كلـ

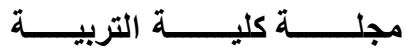

(بل) ابن خلدون، العبر وديوان المبتدأ والخبر في أيام العرب والعجم والبربر من عناصرهم من ذوي السلطان الأكبر

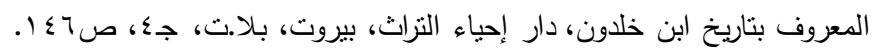

(lv)

(V)

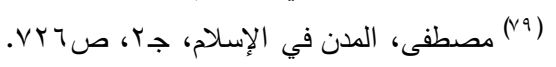

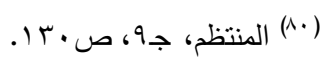

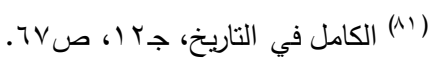

(r) هو علي بن احمد الجرجائي ابو القاسم نجيب الدولة ولد في جرجرايا بسواد العراق وسكن مصر وتتقل في الاعمال

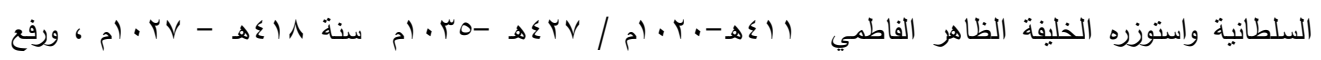



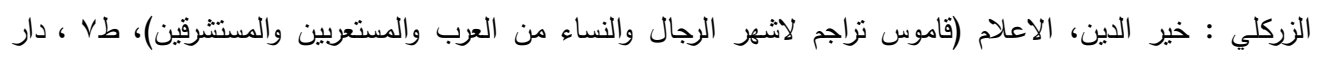

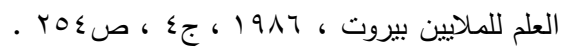

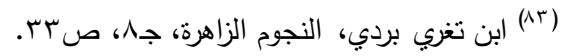

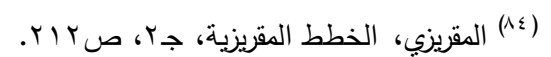

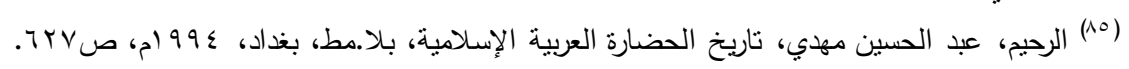

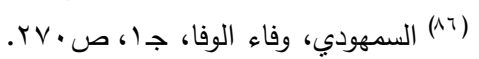



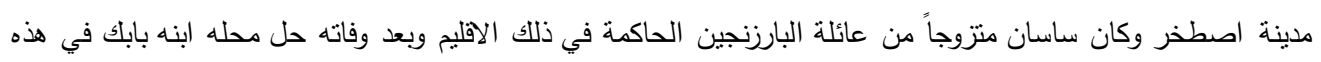

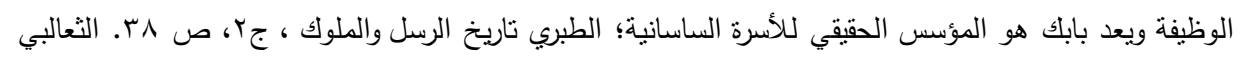

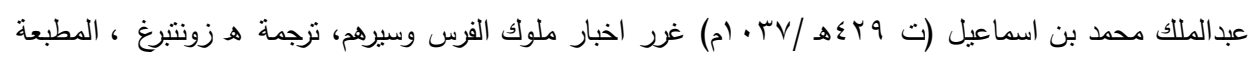

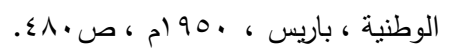

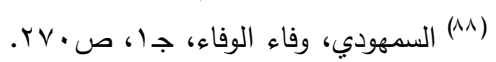

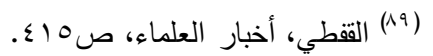

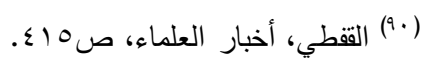

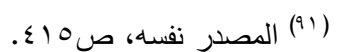

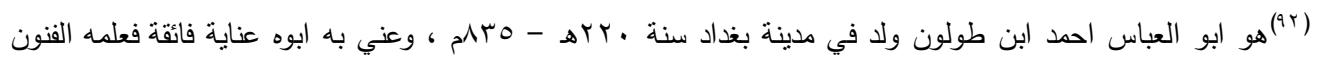







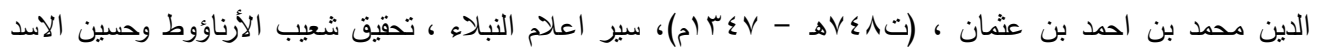

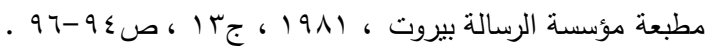

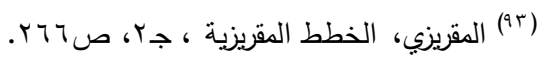


العدد الثاني والأربعون

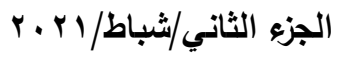

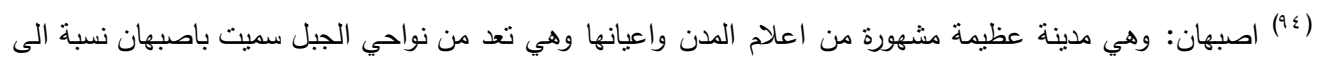

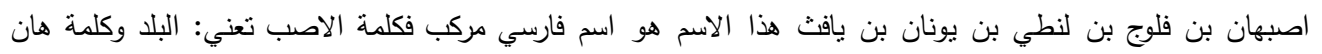

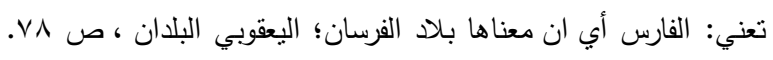

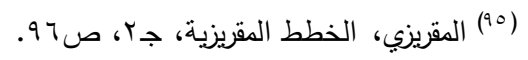

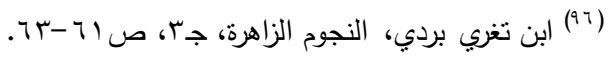

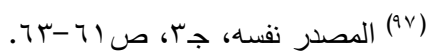

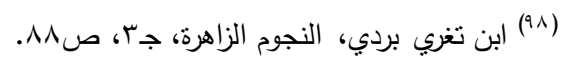

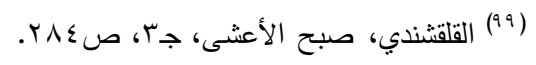

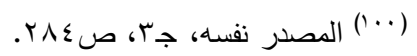

